\title{
MODEL KONSEPTUAL KEPEMIMPINAN, GENDER, DAN DIVERSITAS
}

\author{
Poppy Nurmayanti $\mathbf{M}^{1 *}$, Evi Suryawati ${ }^{2}$, Yohannes Firzal $^{3}$, \\ Yusni Maulida ${ }^{1}$, dan Sinta Ramaiyanti ${ }^{1}$ \\ ${ }^{1}$ Fakultas Ekonomi dan Bisnis Universitas Riau \\ ${ }^{2}$ Fakultas Ilmu Keguruan dan Pendidikan Universitas Riau \\ ${ }^{3}$ Fakultas Teknik Universitas Riau \\ Email:poppy.nurmayanti@lecturer.unri.ac.id
}

\begin{abstract}
This paper presents a conceptual model on leadership, gender, and diversity toward decision making with using role congruity theory. This paper also explore generally whether and why gender may matter for leadership and evaluate views on a feminine/masculine in effectiveness leadership.This paper shows that transactional and transformational leadership are different. Organizations that are dominated by women at the management and administrative levels tend to practice transformational leadership. However, a good leader should combine transformational and transactional leadership types. Recently, considerations of gender and diversity have predominantly focused on differences and similarities between female and male leaders that results from the difference between stereotypes and leadership stereotype. These difference exist worldwide and globalization of management brings to the need to examine this stereotype phenomenon in cross cultural area.
\end{abstract}

Keywords: gender, leadership, diversity, female leader, male leader

\begin{abstract}
Abstrak
Tulisan ini menyajikan model konseptual tentang kepemimpinan, gender, dan diversitas yang dikaitkan dengan pembuatan keputusan dengan menggunakan teori kesesuaian peran. Tulisan ini juga mengeksplorasi apa dan mengapa gender menjadi penting untuk kepemimpinan dan mengevaluasi pandangan tentang feminism/maskulin dalam efektivitas kepemimpinan. Hasil reviu studi ini menunjukkan bahwa kepemimpinan transaksional dan transformasional berbeda. Organisasi yang didominasi perempuan dalam level manajemen dan administrasi, cenderung melakukan praktik kepemimpinan transformasional. Namun, seorang pemimpin yang baik seharusnya mengkombinasikan tipe kepemimpinan transformasional dan transaksional. Saat ini, pertimbangan gender dan diversitas secara dominan berfokus pada perbedaan dan persamaan pemimpin perempuan dan laki-laki yang dihasilkan dari perbedaan antara stereotype dan stereotype kepemimpinan. Perbedaan ini ada di seluruh dunia dan globalisasi manajemen membawa kebutuhan untuk meneliti fenomena stereotip ini di area lintas kultural.
\end{abstract}

Kata kunci: gender, kepemimpinan, diversitas, pemimpin perempuan, pemimpin laki-laki 


\section{PENDAHULUAN}

Isu mengenai kepemimpinan telah banyak dibahas dan didiskusikan sejak lama. Arti penting kepemimpinan sering dikaitkan dengan keberhasilan atau kegagalan bagaimana seorang pemimpin mengelola organisasinya. Ini terkait pula dengan seberapa efektif seorang pemimpin dalam memimpin organisasi. Beberapa kriteria dan ukuran mengenai keefektifan pemimpin telah banyak ditawarkan oleh penulis dan peneliti terdahulu. Mulai dari terkait dengan motif dan sifat, pengetahuan, keahlian, dan kemampuan, visi yang jelas, dan implementasi visi hingga adanya isu gender dan diversitas yang dapat memengaruhi keefektifan dalam memimpin organisasi (Schedlitzki dan Edwards, 2014).

Meskipun proporsi perempuan di tempat kerja telah meningkat dalam beberapa dekade terakhir, keterwakilan perempuan di level tertinggi organisasi atau korporasi masih kurang. Perempuan menempati posisi sebagai chief executive officer (CEO) di Fortune 500 hanya 3,8\% (Underdhal et al 2014) dan sekitar 6\% perempuan yang menempati CEO di perusahaan publik Indonesia dari sektor manufaktur (Nurmayanti 2019). Temuan ini memberikan bukti bahwa perempuan masih sangat kurang terwakili di posisi kepemimpinan elit. Selama beberapa dekade, peneliti telah memberikan penjelasan untuk hal ini (antara lain Underdhal et al 2014; Schedlitzki dan Edwards, 2014).

Salah satu penjelasan tentang kurangnya keterwakilan perempuan dalam posisi kepemimpinan elit adalah masih rendahnya penghargaan terhadap efektivitas perempuan sebagai pemimpin. Hal ini didukung oleh beberapa perspektif teoritis seperti lack of fit theory (teori ketiadaan fit) (Heilman 2001), teori kesesuaian peran (Eagly dan Karau 2002), expectation states theory (Berger et al 1977; Underdhal et al 2014), dan the think managerthink male paradigm (paradigma berpikir manajer-berpikir laki-laki) (Schein 1973; 2007).

Saat ini, organisasi dan korporasi sudah mulai mempertimbangkan perbedaan dan persamaan pemimpin laki-laki dan pemimpin perempuan, dan mempertimbangkan faktor diversitas lainnya seperti kultur, etnis, umur, pendidikan, dan orientasi seksual (Schedlitzki dan Edwards, 2014). Fokus tentang gender memberikan penjelasan yang krusial terutama dalam pandangan stereotypical antara laki-laki/perempuan dan maskulinitas/femininitas, yang telah menjadi pertanyaan dan representasi dalam teori kepemimpinan dan masalah yang banyak didiskusikan.

Sebuah artikel di Psychology Today melaporkan bahwa perempuan lebih baik dan unggul dalam kepemimpinan dibandingkan pria dikarenakan perempuan lebih lebih mungkin 
mengadopsi gaya kepemimpinan kolaboratif dan pemberdayaan. Sementara pria cenderung mengadopsi gaya kepemimpinan perintah, control, dan penegasan kekuasaan (Underdhal et al 2014). Namun, argumen tersebut mendapatkan kritikan bahwa seharusnya studi yang dilakukan tersebut tidak menanyakan perbedaan gender dalam kepemimpinan, melainkan harusnya menanyakan kapan dan mengapa adanya perbedaan gender dalam keefektifan kepemimpinan (Eagly dan Karau 2002; Underdhal et al 2014).

Lebih lanjut, Agly dan Carli (2003) menyatakan bahwa pembahasan tentang gender haruslah menggunakan teori dan metode yang memiliki implikasi bagi kehidupan organisasi. Untuk itu, perlu adanya metaanalisis untuk membahas gender dan efektivitas kepemimpinan dengan mempertimbangkan faktor diversitas.

Tulisan ini menawarkan sebuah model konseptual yang menjelaskan gaya kepemimpinan, gender, dan diversitas yang berhubungan dengan pembuatan keputusan organisasi dari sisi teori kesesuaian peran. Adapun sistematika tulisan ini dimulai dengan pendahuluan, kemudian dilanjutkan dengan membahas telaah literatur dan pengembangan proposisi berdasarkan model konseptual yang diusulkan. Bagian berikutnya mendiskusikan metode penelitian yang digunakan dalam mengembangkan model konseptual kepemimpinan, gender, dan diversitas terkait dalam pembuatan keputusan organisasi. Bagian akhir tulisan ini ditutup dengan menyajikan kesimpulan.

\section{TELAAH LITERATUR DAN PENGEMBANGAN PROPOSISI}

\section{Konsep Kepemimpinan}

Definisi kepemimpinan hingga saat ini masih ambigu. Kesan ambigu ini disebabkan oleh penggunaan istilah yang tidak tepat dalam kepemimpinan, seperti power, otoritas, manajemen, administrasi, kontrol, dan supervisi untuk menggambarkan beberapa fenomena (Yukl, 1989). Bahkan definisi kepemimpinan yang diberikan tergantung pada tujuan masingmasing penulis dan peneliti.

Istilah kepemimpinan (leadership) berasal dari kata dasar "pimpin" (lead), yang berarti bimbing atau tuntun. Dari istilah ini berarti ada dua pihak yang terlibat, yaitu yang dipimpin dan yang memimpin (pemimpin). Pemimpin berarti orang yang memengaruhi pihak lain melalui proses kewibawaan komunikasi sehingga orang lain tersebut bertindak sesuatu dalam mencapai tujuan tertentu. Sementara kepemimpinan (leadership) berarti kemampuan dan kepribadian seseorang dalam mempengaruhi serta membujuk pihak lain agar melakukan tindakan untuk mencapai tujuan yang sama (Kusumawati, 2007). 
Yukl (1989) menyatakan bahwa definisi kepemimpinan melibatkan interaksi antara dua orang atau lebih. Kebanyakan definisi mengenai kepemimpinan mencerminkan asumsi yang melibatkan sebuah proses yang mempengaruhi yang pengaruh intensional yang dilakukan oleh pemimpin terhadap pengikutnya. Sementara House et al., (2004) menyatakan bahwa kepemimpinan merujuk kepada kemampuan individu untuk memengaruhi, memotivasi, dan memampukan orang lain untuk berkontribusi terhadap keefektifan dan kesuksesan organisasi melalui anggotanya.

Dari sejumlah definisi kepemimpinan yang diusulkan oleh penulis dan peneliti terdahulu masih menunjukkan defenisi yang berbeda. Hal ini karena defenisi kepemimpinan yang diberikan terkait dengan siapa yang berpengaruh, tujuan, dan cara mempengaruhi orang lain. Meskipun perilaku kepemimpinan dapat dikonseptualisasikan dalam berbagai dimensi, namun kebanyakan kontennya ditangkap dengan menggunakan dua konstruk yang berasal dari pendekatan Ohio State terhadap kepemimpinan (Yukl (1989).

Konstruk pertama adalah consideration yang merujuk kepada perilaku supervisor yang friendly dan supportive secara interpersonal. Consideration digambarkan sebagai perilaku kepemimpinan yang pemimpin gunakan untuk menciptakan lingkungan yang hangat, bersahabat dan helpfulness (House, 1971; Van Emmerik, 2009). Konstruk kedua adalah initiating structure yang merujuk kepada orientasi tugas dan directive behaviour (Yammarino, et al., 2005; Van Emmerik, 2009). Kepemimpinan dengan perilaku ini menekankan pada penyelesaian tugas, prosedur-prosedur tertentu yang akan diikuti, mengklarifikasi ekspektasi bawahan, dan menentukan jadwal kerja yang akan dilakukan (House, 1971; Van Emmerik, 2009).

Consideration dan initiating structure dipertimbangkan sebagai perilaku kepemimpinan yang independen, pengukuran perilaku pemimpin diletakkan pada suatu kontinum mulai dari level yang rendah hingga level yang tinggi (Yammarino, et al., 2005). Van Emmerik (2009) menggunakan consideration dan initiating structure sebagai indikator fundamental dari pemimpin yang efektif. Alasan lainnya, karena kedua tipe perilaku ini sangat relevan bila dikaitkan dengan isu gender karena stereotypes yang banyak dipegang oleh orang-orang mengenai gaya kepemimpinan laki-laki dan perempuan (Eagly dan Johnson, 1990), laki-laki lebih forceful, dominan, dan dimotivasi untuk dapat mengatasi lingkungannya, sehingga pemimpin laki-laki lebih condong untuk menggunakan gaya kepemimpinan initiating structure. Sebaliknya, pemimpin perempuan dipercaya lebih 
perhatian dengan yang pihak lain (misalnya lebih baik hati, helpful, dan understanding) dan pemimpin perempuan lebih cenderung untuk menggunakan perilaku kepemimpinan consideration.

Perbedaan penting dalam konsepsi seorang pemimpin, disajikan secara ringkas dalam tabel 1 berikut ini (Yukl, 1989).

\section{Tabel 1. Perbedaan Konsepsi Tentang Pemimpin}

\begin{tabular}{|l|l|}
\hline \multicolumn{1}{|c|}{ Konsepsi yang Lebih Luas } & \multicolumn{1}{c|}{ Konsepsi yang Lebih Terbatas } \\
\hline $\begin{array}{l}\text { 1. Seseorang yang memengaruhi anggota } \\
\text { kelompok ("distributed leadership") }\end{array}$ & $\begin{array}{l}\text { 1. Seseorang yang paling berpengaruh } \\
\text { terhadap anggota kelompok yang lain } \\
\text { ("focused leadership") }\end{array}$ \\
$\begin{array}{l}\text { 2. Seseorang yang memengaruhi anggota } \\
\text { kelompok dalam banyak cara }\end{array}$ & $\begin{array}{l}\text { 2. Seseorang yang memengaruhi perilaku } \\
\text { anggota secara sistematis mengenai } \\
\text { perolehan tujuan kelompok. }\end{array}$ \\
$\begin{array}{l}\text { 3. Seseorang yang mempengaruhi anggota } \\
\text { kelompok untuk patuh dengan rela atau } \\
\text { tidak rela }\end{array}$ & $\begin{array}{l}\text { 3. Seseorang yang memperoleh komitmen } \\
\text { anggota kelompok dalam memenuhi } \\
\text { permintaannya }\end{array}$ \\
\hline
\end{tabular}

Sumber: Yukl (1989: 4)

Dari tabel di atas dapat dikatakan bahwa kepemimpinan mencakup aspek kemampuan menggerakkan, mengerahkan, dan mempengaruhi orang-orang yang berada dalam lingkup kepemimpinan seorang pemimpin untuk melaksanakan pekerjaan demi tercapainya tujuan. Menurut Kusumawati (2007) dari definisi tersebut memberikan tiga implikasi, yaitu: (1) kepemimpinan meliputi penggunaan pengaruh dan semua hubungan dapat melibatkan kepemimpinan, (2) kepemimpinan mencakup pentingnya proses komunikasi, yang bisa mempengaruhi perilaku dan prestasi kerja pengikutnya, dan (3) kepemimpinan memfokuskan pada pencapaian tujuan, karena pemimpin yang efektif harus berhubungan dengan tujuan individu, kelompok, dan organisasi.

\section{Keefektifan Kepemimpinan}

Secara umum, keefektifan pemimpin dapat dilihat dari kesuksesan pimpinan dalam tugas dan tercapainya tujuan organisasi. Ukuran yang biasa digunakan untuk menilai keefektifan kepemimpinan beragam, yang intinya adalah untuk melihat sejauhmana unit organisasi dari pemimpin tersebut dapat melaksanakan tugasnya secara berhasil mencapai tujuannya. Indikator yang digunakan misalnya tercapainya profit yang tinggi, peningkatan penjualan, perluasan pangsa pasar, return on investment, return on asset, produktivitas, kos 
per unit output, dan kos dalam hubungannya dengan anggaran pengeluaran bahwa. Bahkan sikap atasan, rekan, maupun bawahan terhadap pimpinan juga dapat merupakan indikator keefektifan pimpinan (Handriana, 2011).

Sarana yang tepat untuk mengukur keefektifan pimpinan adalah menggunakan kuesioner dan wawancara. Beberapa indikator lain yang perlu dipertimbangkan dalam penilaian keefektifan pimpinan dapat menggunakan tingkat absensi, tingkat keluar masuk karyawan, keluhan, komplain pada manajemen yang lebih tinggi, permintaan untuk transfer, pelambatan pekerjaan, dan adanya sabotase.

Yukl (1989) menyatakan bahwa adakalanya, keefektifan pimpinan diukur dalam bentuk besarnya kontribusi pimpinan pada kualitas proses kelompok seperti persepsi pengikut atau pengamat dari luar. Misalnya dengan melihat kerja sama anggota, motivasi anggota, penyelesaian masalah, pembuatan keputusan, dan resolusi konflik diantara anggota, termasuk dalam berkontribusi terhadap efisiensi spesialisasi peran, aktivitas organisasi, akumulasi sumber daya, serta kesiapan kelompok untuk menangani perubahan dan krisis. Kontribusi lainnya dari pemimpin adalah pemimpin dapat memperbaiki kualitas kerja, membangun kualitas percaya diri pengikut, meningkatkan keterampilan bawahan, dan memberikan kontribusi bagi pertumbuhan psikologis dan pengembangan bawahan.

Berkaitan dengan konsep kepemimpinan, Yukl (1989) menawarkan sepuluh fungsi kepemimpinan yang penting untuk mempertinggi kerja kolektif dalam tim dan organisasi, sebagai esensi dari kepemimpinan efektif, yaitu: (1) membantu interpretasi atas maksud kejadian, (2) menciptakan alignment antara sasaran dan strategi, (3) membangun komitmen tugas dan optimisme, (4) membangun kepercayaan dan kerja sama, (5) penguatan identitas kolektif, (6) mengorganisir dan mengkoordinasi kegiatan, (7) mendorong dan memfasilitasi pembelajaran kolektif, (8) memperoleh sumber daya yang diperlukan dan dukungan, (9) mengembangkan dan memberdayakan orang-orang, dan (10) menegakkan keadilan sosial dan moralitas.

\section{Konsep Gender}

Gender diartikan sebagai perbedaan yang tampak antara laki-laki dan perempuan dilihat dari segi nilai dan tingkah laku (Kusumawati, 2007). Ini senada dengan definisi yang diajukan oleh Women's Studies Encyclopedia dalam Kusumawati (2007) yang menyatakan bahwa gender adalah suatu konsep kultural yang berupaya membuat pembedaan (distinction) dalam hal peran, perilaku, mentalitas, dan karakteristik emosional antara laki-laki dan 
perempuan yang berkembang dalam masyarakat. Istilah gender juga digunakan untuk menunjukkan pembagian kerja bagi laki-laki dan perempuan, dalam konteks ini penggunaan istilah gender dikaitkan dengan kepemimpinan.

Beberapa literatur membahas masalah gender dengan tidak melepaskan dengan stereotype dan peran gender. Stereotype gender didefinisikan sebagai aspek sosiologis, antropologis, dan kultural dari peran feminin dan maskulin. Peran gender adalah apa yang diharapkan, ditentukan, atau dilarang bagi satu jenis kelamin tertentu. Dengan kata lain, stereotype gender berkaitan dengan ciri sifat dan karakteristik psikologis yang tepat untuk laki-laki dan perempuan, sementara peran gender berkaitan dengan perilaku yang terekspresi dalam peran sosial yang dimainkannya (Handayani dan Novianto, 2004).

Jackson dan Parry (2011) mengajukan pertanyaan yang berkaitan dengan kepemimpinan yaitu apakah dan mengapa ada perbedaan antara pemimpin laki-laki dan perempuan. Awalnya studi kepemimpinan organisasional lebih banyak membahas mengenai kepemimpinan laki-laki. Kemudian studi tersebut banyak dikritik, karena dianggap terlalu maskulin. Baru pada tahun 1990an, bermunculan studi kepemimpinan feminisasi yang dipandang sebagai keunggulan strategik untuk keefektifan organisasional (Jackson dan Parry, 2011). Kepemimpinan transformasional juga dinyatakan untuk menunjukkan sifat feminin dan perilaku sebagai keunggulan kepemimpinan. Boatwright dan Forrest (2007) dalam Handriana (2011) menyatakan bahwa perempuan lebih menyukai untuk menafsirkan kepemimpinan dalam bentuk transformasi, sedangkan laki-laki lebih menyukai gaya kepemimpinan dalam bentuk transaksi. Kepemimpinan transformasional didefinisikan sebagai suatu proses di mana pemimpin dan pengikut meningkatkan satu dan yang lainnya ke level moralitas dan motivasi yang lebih tinggi (Yukl, 1989).

Namun, bila kita kaitkan gender dan kepemimpinan, masih terdapat pandangan kritis mengenai stereotype gender. Banyak pemimpin perempuan yang menghadapi masalah dalam karirnya. Seringkali masalah kepemimpinan perempuan dikaitkan dengan tugas perempuan seperti mengasuh anak dan tugas perempuan yang selalu dibelakang. Hal ini merupakan dampak dari dominant societal dan struktur budaya lintas organisasi dan negara (Schedilizki dan Edwards, 2014). Namun apa yang menjadi pertimbangan lebih lanjut adalah apakah concern kita untuk perbedaan gender seharusnya difokuskan pada 'body' (seperti laki-laki atau perempuan), atau pada karakteristik personal (seperti feminin atau maskulin) atau ditentukan oleh interaksi dari keduanya. Jika pertanyaannya mengenai equality, maka ini 
tentu masih banyak yang perlu dilakukan untuk membongkar stereotype gender dalan masyarakat modern, organisasi, dan kepemimpinan, sama halnya untuk menyatakan bahwa masalah gender penting untuk kepemimpinan.

\section{Literatur Terdahulu tentang Gender dalam Konteks Kepemimpinan}

Perbedaan antara pemimpin laki-laki dan perempuan telah banyak diteliti, terutama sejak tahun 1970an, namun semuanya memberikan hasil yang beragam (Eagly dan Carli, 2003; Eagly et al., 1995). Belum ada bukti yang kuat yang menyatakan bahwa pemimpin perempuan lebih atau kurang efektif dibandingkan pemimpin laki-laki, dan perbedaan yang konsisten dalam sifat (traits) dan perilaku antara pemimpin laki-laki dan perempuan (Powell, 1990).

Pembahasan mengenai gender tidak terlepas dari isu kemitraan dan keadilan peran sosial antara laki-laki dan perempuan, yang dikonstruksikan oleh agama, adat, dan kultur (Handriana, 2011). Kebanyakan literatur dan studi mengenai kepemimpinan dan manajemen dikembangkan oleh para laki-laki, dan beberapa teori organisasional yang dikembangkan pun juga berdasarkan survei yang dilakukan pada manajer atau pemimpin laki-laki. Hal ini bukanlah hal baru, mengingat pemimpin laki-laki lebih banyak dan lebih diterima secara budaya dan norma sosial. Sementara literatur dan hasil studi mengenai perempuan dan kepemimpian masih dianggap bias, kontradiksi, dan paradok. Ini menunjukkan dominasi maskulin dalam perilaku kepemimpinan dan dinamika manajemen (Elliot dan Stead, 2008).

Munculnya sisi feminisme dalam studi kepemimpinan, mempertimbangkan keberadaan perempuan berusaha untuk memperbaiki perspektif yang beriorientasi laki-laki (sisi maskulin). Beberapa studi menemukan adanya perbedaan gender dalam perilaku kepemimpinan, serta penelitian lain menunjukkan hasil yang berbeda (Lewis dan Fagenson Eland, 1998) dan biasanya dilakukan dnegan meta analisis. Misalnya studi yang dilakukan oleh Eagly dan Johnson (1990) dan Underdahl et al., (2014), yang menunjukkan bahwa pemimpin perempuan tidak lagi menggunakan asumsi stereotype berdasarkan perilaku kepemimpinan feminin versus maskulin. Pemimpin perempuan tidak ditemukan menjadi lebih interpersonal dan kurang berorientasi tugas dibandingkan pemimpin laki-laki. Eagly dan Johannesen-Schmidt (2001) menemukan bahwa perempuan lebih banyak menghadapi hambatan untuk menjadi pemimpin ketimbang laki-laki, tetapi sedikit kesepakatan yang menjelaskan mengenai perbedaan atau kesamaan dalam perilaku kepemimpinan. 
Review metaanalisis yang dilakukan oleh Dobbins dan Platz (1986) mengindikasikan bahwa pemimpin perempuan dan laki-laki mempunyai perilaku kepemimpinan yang seimbang antara consideration dan initiating structure. Manajer laki-laki dalam studi Lewis dan Fagenson-Eland (1998) menunjukkan bahwa manajer laki-laki mempunyai perilaku initiating structure yang lebih tinggi daripada manajer perempuan. Studi meta analisis yang dilakukan oleh Eagly (2007) menunjukkan bahwa terdapat perbedaan kecil dalam perilaku kepemimpinan laki-laki dan perempuan. Perempuan lebih berperilaku kepemimpinan transformasional dan lebih rewarding dalam kepemimpinannya, sementara laki-laki lebih menggunakan initiating structure dan lebih menunjukkan laissez-fair leadership. Karena studi ini mayoritas dilakukan di barat, terutama di Amerika, hasilnya belum dapat digeneralisasi, dan diperlukan validasi lintas masyarakat dalam hal ini.

Hasil studi Eagly et al., (2003) menyimpulkan bahwa pemimpin perempuan lebih cenderung bersifat transformasional dan lebih menggunakan dalam perilaku reward kontinjen dibandingkan pemimpin laki-laki. Meskipun perbedaannya kecil, Eagly et al., (2003) menyimpulkan bahwa temuan tersebut robust dan disajikan keunggulan feminin sebagai perilaku leader yang berhubungan dengan keefektifan pemimpin yang lebih tinggi. Sementara itu, temuan dari studi Elliot dan Stead (2008) menunjukkan bahwa ide kontemporer mengenai gender dan kepemimpinan menyebabkan karakteristik feminin, memberikan perempuan keunggulan di tempat kerja, ketika gaya organisasionalnya partisipatif dan demokratis.

Meskipun adanya stereotypes antara laki-laki dan perempuan yang agak kuat (Glick, et al., 2004) dan stabil (Schein, 2007), terdapat bukti yang terbatas untuk mendukung hal ini. Eagly dan Johnson (1990) dalam reviewnya tidak menemukan konfirmasi mengenai gambaran stereotype dalam hal laki-laki lebih pada orientasi tugas dan perempuan lebih pada orientasi hubungan. Namun demikian, Eagly dan Johnson (1990) menemukan bahwa perempuan lebih demokratis atau gaya partisipatif, dan kurang bersifat otokrasi atau directive style dibandingkan laki-laki, ini berarti bahwa konsisten dengan ekspektasi stereotype. Eagly et al., (2003) menunjukkan bahwa manajer perempuan dibandingkan manajer laki-laki, lebih menggunakan kepemimpinan transformatif dan lebih menunjukkan perilaku rewarding, sementara manajer laki-laki lebih menekankan perhatiannya kepada kesalahan bawahannya.

Gardiner dan Tiggemann (1999) menemukan bahwa manajer perempuan lebih berorientasi pada kepemimpinan interpersonal dibandingkan manajer laki-laki, namun ini terjadi hanya di industri yang didominasi oleh perempuan. Ketika perempuan berada dalam 
industri yang didominasi laki-laki, kondisi ini akan mengubah gaya hubungan manajer perempuan tersebut, yaitu manajer perempuan mengurangi perbedaan dan stereotyping oleh manajemen laki-laki.

Gardiner dan Tiggemann (1999) menyatakan bahwa perempuan yang berada di lingkungan yang didominasi laki-laki akan memiliki gaya kepemimpinan yang sama dengan manajer laki-laki, karena mereka dipilih oleh laki-laki. Namun harus dicatat, kesimpulan studi ini berdasarkan studi yang dilakukan di masyarakat barat, terutama dalam konteks masyarakat mayoritas Amerika. Sehingga hasil studi tersebut tidak dapat digeneralisasi untuk kepemimpinan global, karena mayoritas studi-studi yang memfokuskan masalah gender dan societal kultur masih sedikit dilakukan (Dickman et al., 2005).

Eagly dan Carli (2003) menyimpulkan bahwa peran perempuan yang semakin meningkat ke dalam semua level. Mulai dari level individu, organisasional, hingga level kultural. Pada level individu, secara spesifik, karakteristik perempuan telah berubah, pada level organisasional, peran kepemimpinan telah berubah dan praktik-praktik yang merupakan hambatan untuk mempromosikan perempuan ke dalam posisi otoritas telah terkikis. Begitupula pada level kultural, penunjukkan pemimpin perempuan mempunyai simbol perubahan organisasional.

Hal ini dapat dijelaskan berikut. Alasan pertama, perubahan peran perempuan adalah karena terjadinya pergeseran peran perempuan dari peran domestik (rumah tangga) ke tenaga kerja, perempuan memiliki peran baru yang tak kalah penting (Eagly et al., 2000). Investasi human capital perempuan yang meningkat, atribut psikologi perempuan dan perilaku telah berubah dan mempunyai peran yang sama dengan laki-laki. Terutama perannya dalam kepemimpinan yang menunjukkan bahwa aspirasi karir mahasiswa perempuan (Astin et al., 1997), perempuan menjadi asertif, dominan, dan maskulinitas, dan nilai perempuan terhadap atribut pekerjaan seperti kebebasan, tantangan, kepemimpinan, prestise, dan power (Konrad, et al., 2000) semuanya telah sama dengan laki-laki. Meskipun terjadinya perubahan seperti ini, perempuan menjadi lebih maskulin, tidak berarti menurunkan kualitas feminin perempuan (Diekman dan Eagly, 2000).

Alasan kedua adalah beberapa penelitian mengindikasikan bahwa ketidakseimbangan peran pemimpin dan peran perempuan telah menurun. Schein (2001) menyatakan bahwa di Amerika, tidak hanya di beberapa negara, perempuan, telah mengadopsi peran manajerial androgynous view. Walaupun deskripsi definitif tren sekuler dalam pandangan stereotype 
pemimpin dan manajer menantikan meta analisis yang tepat, perubahan ini telah menjadi berubah. Ini konsisten dengan ide cultural lag (Brinkman dan Brinkman, 1997), aspek ideologikal kultur, termasuk stereotype, semakin pelan perubahan yang terjadi dibandingkan pergeseran struktur sosial seperti konten aktual dari peran. Namun demikian, perubahan gradual dalam pemimpin stereotype tidak konsisten dengan perubahan dalam perubahan kepemimpinan yang menekankan kualitas kepemimpinan yang lebih konsisten dengan peran perempuan dibandingkan karakterisasi tradisional kepemimpinan. Karena perubahan peran kepemimpinan, proporsi perempuan semakin besar memberikan lingkuangan yang welcome bagi kompetensi manajerial perempuan.

Alasan ketiga adalah karena praktik organisasional telah berubah. Peningkatan peran perempuan dalam praktik organisasioanl, memberikan kesempatan bagi perempuan untuk ikut serta dalam berbagai organisasional, seperti keterlibatan perempuan di legislatif, politik, bisnis, dan lain-lain. Survei yang dilakukan oleh Statistiches Bundesamt (2005) Jerman menunjukkan bahwa terdapat 21 persen perempuan yang menempati posisi eksekutif puncak (seperti direktur dan managing director). Menurut lembaga survei Amerika, Catalyst (2012), menunjukkan perempuan yang memegang posisi CEO berdasarkan Fortune 500 sebesar 5,2 persen, dan 5,4 persen berdasarkan Fortune 1000. Survei tersebut menunjukkan masih rendahnya keterlibatan perempuan dalam organisasi, meskipun pada dasarnya terjadinya peningkatan perempuan menjadi pemimpin di organisasi.

Alasan selanjutnya adalah karena kultur telah berubah. Dalam pandangan peran pemimpin dan praktik organisasional, pemimpin perempuan telah menjadi simbolisasi tipe kepemimpinan baru yang mengandung keefektifan dan sinergi yang lebih besar dibandingkan kepemimpinan sebelumnya (Adler, 1999 dalm Eagly dan Carli, 2003). Penunjukkan perempuan sebagai pemimpin berangkat organisasi dari praktik masa lalu dan membantunya untuk menangkap simbol perubahan inovasi dan kemajuan. Simbolisme kultural baru diisi sebagai bagian dari proses pergeseran kepemimpinan dimulai dari adanya praktik bisnis tidak etis dan ilegar dari beberapa organisasi yang dipimpin oleh laki-laki (Eagly dan Carli, 2003).

Eagly dan Carli (2003) menyatakan bahwa pergeseran 'simbol' kepemimpinan ini membawa perempuan ke dalam posisi yang lebih tinggi sebagai dorongan yang mendasari klaim keuntungan perempuan. Bagaimanapun, fokus pada isu perbedaan dalam gaya dan keefektifan kepemimpinan, bukti empiris memberikan kesimpulan yang lebih sempit. Untuk 
itu masih perlu diteliti kembali dengan menghubungkannya dengan kultur dalam kondisi organisasi modern saat ini.

Sejak akhir 1970an, studi gender telah berkembang dengan beragam fokus penelitian. Seperti berfokus pada kepemimpinan, kekuasan, otoritas, karir, budaya organisasi gender, emosi, kewirausahaan, dan keseimbangan kerja-hidup (Vasconcelos 2018), namun penelitian di area gender yang berfokus pada kepemimpinan masih belum memiliki konsensus. Lebih lanjut, teori kepemimpinan telah menempatkan stereotip gender, misalnya baik perilaku maskulin maupun feminin tidak menentukan untuk memperoleh pemimpin yang efektif (Powel 2012). Dengan kata lain, baik gaya kepemimpinan yang maskulin/berorientasi tugas ataupun feminin/hubungan berorientasi gaya kepemimpinan tidak dapat mencapai tujuan di banyak organisasi (Vasconcelos 2018).

\section{Teori Kesesuaian Peran (Role Congruity Theory)}

Studi ini dibangun dengan menggunakan teori kesesuaian peran (role congruity theory). Teori kesesuaian peran merupakan bagian dari teori peran sosial, yang berargumen bahwa individu mengembangkan deskriptif dan preskriptif ekspektasi peran gender dari perilaku orang lain berdasarkan pada divisi tenaga kerja dan jenis kelamin (Eagly dan Johnson 1990). Berdasarkan peran sosial ini, perempuan digambarkan dan diharapkan lebih komunal, berorientasi hubungan, lebih mengayomi dibanding laki-laki. Sementara, laki-laki diyakini dan diharapkan lebih agentik, tegas, dan mandiri daripada perempuan.

TKP dibangun dengan mempertimbangkan kesesuaian antara peran gender dan peran kepemimpinan. Teori ini mengusulkan bahwa orang cenderung memiliki keyakinan yang berbeda tentang karakteristik pemimpin dan perempuan, dan memiliki keyakinan yang sama tentang karakteristik pemimpin dan laki-laki (Eagly dan Karau 2002). Lebih lanjut, teori kesesuaian peran menjelaskan bahwa ketika seseorang berada pada posisi kepemimpinan, perempuan cenderung lebih banyak menghadapi ketidaksetujuan dibandingkan laki-laki. Kepemimpinan perempuan dianggap melanggar peran gender (Eagly dan Karau 2002).

Eagly dan Karau (2002) juga mengusulkan bahwa persepsi ketidaksesuaian ini dapat bervariasi tergantung konteks kepemimpinan dan karakteristik pemimpin. Eagly et al (1995) menemukan bahwa peran kepemimpinan membutuhkan perilaku yang konsisten dengan partisipasi dan pertimbangan terbuka tentang feminin. Sementara, peran pemimpin membutuhkan kemampuan untuk mengarahkan dan mengendalikan orang agar dinilai maskulin oleh lingkungan. 
Atas dasar gagasan tersebut, penulis berargumen bahwa teori kesesuaian peran dapat diterapkan pada laki-laki yang berada pada posisi kepemimpinan tertentu yang mungkin dianggap tidak sesuai dengan karakteristik yang terkit dengan peran gender laki-laki. Organisasi telah berkembang cepat dan mengglobal, sehingga gaya kepemimpinan yang lebih feminin diperlukan untuk menekankan komunikasi partisipatif dan terbuka untuk menjadi berhasil (Underdhal et al 2014).

\section{Pengembangan Proposisi Berdasarkan Model Konseptual}

Berdasarkan konsep kepemimpinan dan gender (Dwiri dan Okatan 2021), penulis menyoroti konsep gender dengan membedakan pemimpin laki-laki dan perempuan dalam membuat keputusan yang efektif dilihat dari gaya kepemimpinan transformasional dan transaksional. Penulis juga mempertimbangkan isu diversitas yang dikemukan oleh Schedlitzki dan Edwards, (2014). Gambar 1 berikut ini menyajikan blok bangunan dari studi ini sebagai dasar model konseptual studi ini untuk mengembangkan proposisi studi ini.

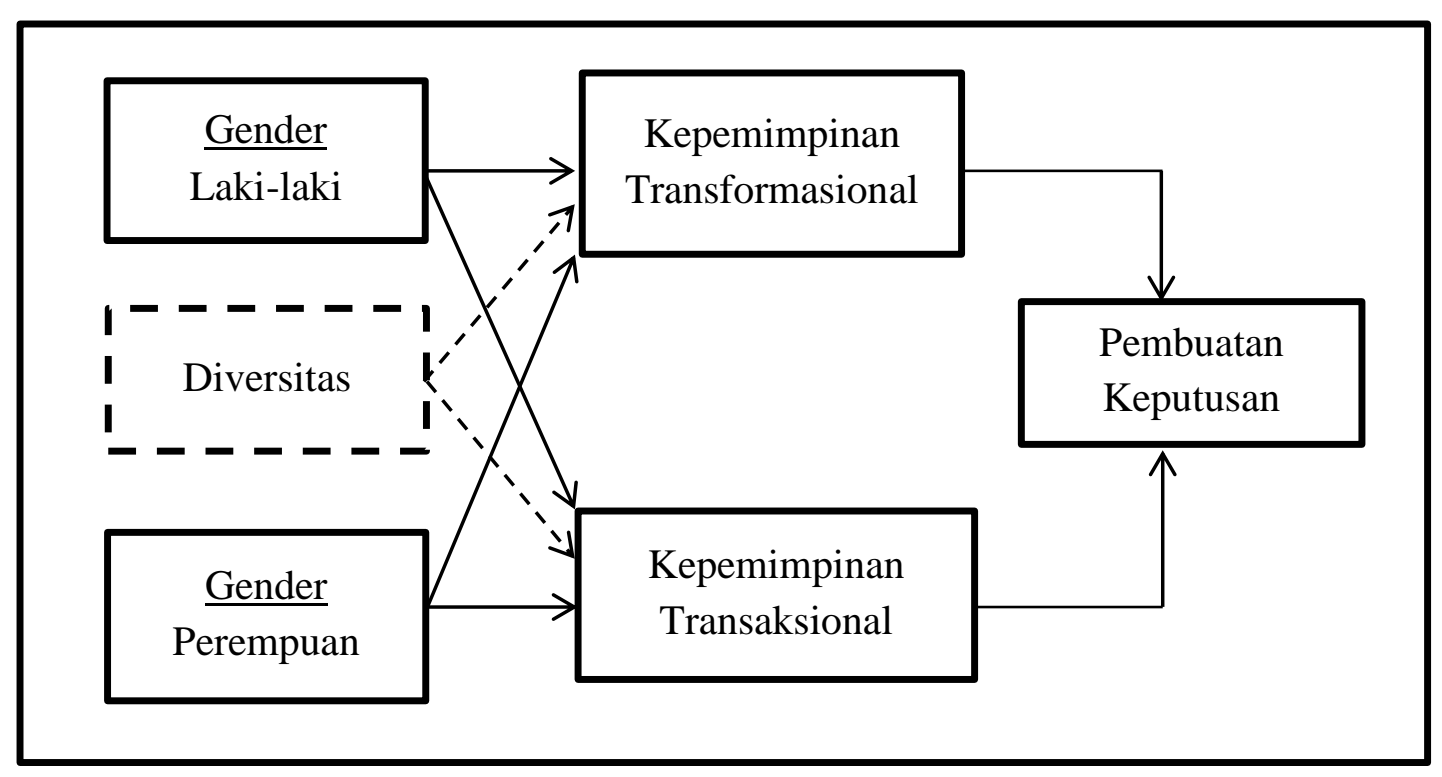

Gambar 1. Model konseptual gender, diversitas, dan kepemimpinan terkait dengan pembuatan keputusan.

\section{Pembuatan Keputusan}

Pembuatan keputusan merupakan salah satu faktor untuk menilai keberhasilan seorang pemimpin. Penelitian di area gender tentang kepemimpinan menunjukkan bahwa terdapat perbedaan dalam pembuatan keputusan dari laki-laki dan perempuan (Dwiri dan Okatan 2021). Perbedaan tersebut menyangkut esensi tindakan, kegiatan yang terlibat, dan penciptaan 
hubungan kerja. Studi terdahulu menunjukkan bahwa perempuan cenderung mengandalkan untuk membangun dan memelihara hubungan kerja yang baik untuk merampingkan proses bagi staf junior dan senior. Di sisi lain, pria jarang berkonsentrasi pada hubungan kerja karena mereka berkonsentrasi pada hasil (Yaqoub 2018; Dwiri dan Okatan 2021).

\section{Gender dan Kepemimpinan}

Peran gender adalah tindakan yang diterima atau diprediksi dalam sosial budaya untuk laki-laki dan perempuan. Lebih lanjut, umumnya peran gender menyiratkan apa yang dianggap sebagai peran yang sesuai dengan budaya untuk laki-laki dan perempuan (Dwiri dan Okatan 2021; Smith dan Wang 1996; Smith dan Bond 1993). Menurut teori peran sosial, peran gender dibagi menjadi dua karakter. Pertama, karakter agen laki-laki yang menunjukkan ketangguhan, kekuatan, superioritas, dan kepercayaan diri. Kedua, karakter agen perempuan menunjukkan emosi, kebajikan, suka menolong, kepekaan, dan kelembutan interpersonal (Eagly dan Schmidet; Eagly dan Johnson 1990).

Secara historis, pemimpin cenderung dipegang oleh laki-laki dan perempuan memiliki banyak tantangan untuk menjadi pemimpin (Eagly 2002). Studi eksperimen menunjukkan bahwa berdasarkan jenis kelamin pemimpin, bawahan cenderung menunjukkan reaksi psikologis dan kebiasaan kerja yang berbeda dan menunjukkan persetujuan yang berbeda dari manajer perempuan dan laki-laki (Vecchio dan Bullis 2001).

Bukti empiris lain juga menunjukkan bahwa sebagian besar manajer perempuan memperoleh penilaian yang tidak menguntungkan, terutama karena ekspektasi peran gender berbeda dengan kecakapan merek untuk bekerja (Vecchio dan Bullis 2001; Dwiri dan Okatan 2021). Lebih lanjut, Powell (1990) menemukan bahwa orang-orang cenderung berekspektasi bahwa manajer yang sukses dekat dengan citra kepemimpinan yang dipegang oleh laki-laki. Manajer laki-laki dipandang sebagai manajer yang sukses dibandingkan manajer perempuan.

\section{Gaya Kepemimpinan}

Paradigma kepemimpinan transaksional transformasional telah menjadi tema umum dalam literatur kepemimpinan dalam beberapa tahun terakhir (Avolio dan Howell 1992; Hater dan Bass 1988; Seltzer dan Bass 1990). Dibandingkan dengan tugas versus kepemimpinan yang berorientasi pada hubungan, gagasan kepemimpinan transformasional-transaksional dipandang sebagai kontinum yang memungkinkan individu untuk menggunakan karakteristik 
transformasional dan transaksional pada saat yang sama (Seltzer dan Bass 1990). Gaya kepemimpinan transformasional dan transaksional dijelaskan berikut ini.

Kepemimpinan transformasional. Kepemimpinan transformasional adalah jenis kepemimpinan yang berfokus pada perubahan budaya revolusioner yang berkontribusi pada visi organisasi (Nayab 2010; Dwiri dan Okatan 2021). Pemimpin transformasi bergantung pada kebutuhan masa depan dan lebih peduli tentang masalah jangka panjang (Saeed et al 2014). Kepemimpinan transformasional memasuki gaya kepemimpinan yang memfasilitasi kreativitas bawahan dan perubahan iklim tempat kerja (Bass 1997). Lebih lanjut, pemimpin transformasional bertujuan untuk menginspirasi dan memberdayakan tenaga kerja mereka untuk mencapai target organisasi (Bass 1997). Saat menggunakan gaya ini, diperlukan tingkat motivasi intrinsik, kepercayaan diri, pengabdian, dan loyalitas yang lebih tinggi dari pengikut (Bass dan Avolio 1994). Pemimpin harus memiliki kemampuan empatik yang baik (Bass 1997). Gaya kepemimpinan transformasi memiliki efek positif yang kuat pada karyawan, komunitas, dan hasil organisasi dan sebuah penelitian mengungkapkan bahwa pengikut lebih terinspirasi, aktif, dan senang dengan pemimpin transformasional (Bass dan Avolio 1994).

Dari temuan studi terdahulu dan penjelasan di atas, penulis memasukkan aspek kepemimpinan transformasional dari pemimpin perempuan sebagai faktor yang memengaruhi pembuatan keputusan dengan proposisi berikut ini.

Proposisi 1a. Pemimpin perempuan dalam kepemimpinan transformasional berdampak terhadap pembuatan keputusan.

Kepemimpinan transaksional. Kepemimpinan transaksional berfokus pada penggunaan otoritas hukum dalam sistem birokrasi organisasi (Dwiri dan Okatan 2021). Kenyataannya adalah ketika mereka mempertimbangkan tawaran pekerjaan, anggota tim berjanji untuk mengikuti atasan mereka dalam semua kasus yang sah. Kelangsungan kepatuhan bawahan ini bergantung pada ikatan kepercayaan bersama dan kesediaan pemimpin untuk menegakkan kesepakatan yang dibuat. Pekerjaan yang baik akan dihargai, dan kinerja yang buruk tidak akan dihargai, tetapi pemimpin akan campur tangan jika keadaan menjadi buruk (Bass 1990). Gaya kepemimpinan ini berupaya untuk meningkatkan produktivitas karyawan dengan menggunakan motivasi ekstrinsik (Dwiri dan Okatan 2021).

Pemimpin transaksional akan terampil dan efektif dalam lingkungan yang stabil dan dapat diprediksi. Pemimpin akan memenuhi kebutuhan pendukungnya dengan imbalan kinerja yang sesuai dengan ekspektasi (Lowe et al 1996). Dari temuan studi terdahulu dan 
penjelasan di atas, penulis memasukkan aspek kepemimpinan transaksional dari pemimpin perempuan sebagai faktor yang memengaruhi pembuatan keputusan dengan proposisi berikut ini.

Proposisi 1b. Pemimpin perempuan dalam kepemimpinan transaksional berdampak terhadap pembuatan keputusan.

\section{Diversitas dan Kepemimpinan}

Istilah diversitas memberikan "payung" untuk mendeskripsikan banyak fokus, seperti etnis, umur, gender, pendidikan, kelas, dan orientasi seksual. Diversitas merupakan istilah yang menjadi banyak perhatian dalam bidang manajemen dan bisnis selama beberapa dekada terakhir untuk menjelaskan berbagai latar belakang karyawan untuk bekerja sama (Schedlitzki dan Edwards, 2014).

Rickards (2012) menekankan diversitas pada level hirarki dan kompleksitas kerja pemimpin ekspariat. Dalam studi kepemimpinan, diversitas tidak terlalu mendapat perhatian, kecuali pada gender. Diversitas yang sebelumnya kurang mendapat perhatian adalah studi lintas kultural tentang kepemimpinan (termasuk pemimpin ekspatriat), manajemen dan tenaga kerja (Schedlitzki dan Edwards, 2014).

Kepemimpinan ekspatriat. Sebenarnya kepemimpinan ekspatriat belum banyak mendapat perhatian dalam studi kepemimpinan. Biasanya kepemimpinan ekspatriat dikaitkan dengan kultur suatu negara dan organisasi. Black dan Mendenhall (1990) dan Schedlitzki dan Edwards (2014) menyelidiki hubungan antara technical training dan kompentensi pemimpin ekspatriat dalam lintas kultur dan komparatif literatur manajemen. Namun studi tersebut masih belum menyelidiki atau mengeksplorasi hubungan pemimpin ekspatriat dan pengikut lokal. Schedlitzki dan Edwards (2014) menekankan pada culture shock bahwa banyak ekspatriat yang pengalamannya tidak sesuai dengan cultural training dan kesadaran. Ekspatriat barat sering kesulitan untuk menyesuaikan kultur lokal dengan perilaku dan sikapnya.

Hubungan pemimpin ekspatriat dan pengikutnya dibatasi oleh kompleksitas ketidakcocokan kultur, terutama dalam jangka waktu pendek. Persepsi ekspatriat sebagai 'seseorang asing' oleh pengikut lokal dan adanya persepsi dalam konteks pengikut lokal sebagai lingkungan yang 'asing' bagi pemimpin ekspatriat dapat menciptakan ketegangan yang sulit untuk diatasi. Untuk itu diperlukan banyak penelitian untuk membongkar dan 
memahami kompleksitas ini dan isu kultur yang mempengaruhi hubungan pemimpin dan pengikut (bawahannya).

Manajemen dan tenaga kerja. Diversitas berikutnya berkaitan dengan manajemen dan tenaga kerja. Schedlitzki dan Edwards (2014) menjelaskan bahwa pekerjaan yang dilakukan pada diversitas manajemen dalam kelompok berpotensi untuk memberikan manfaat dan tantangan untuk kepemimpinan dan organisasi. Keuntungan utama dari adanya tenaga kerja yang beragam adalah dapat meningkatkan kreatifitas dan inovasi, dan meningkatkan potensi bakat dan ini berguna untuk proses pembuatan keputusan yang lebih balanced dalam pandangan dan nilai-nilai yang berbeda, yang dibawa oleh keberagaman tenaga kerja.

Schedlitzki dan Edwards (2014) mengingatkan bahwa adanya diversitas yang besar dalam tenaga kerja juga memberikan kesempatan untuk terjadinya ketidakpercayaan dan konflik, bila menurunnya komitmen dan identitas dalam kelompok. Adanya pandangan mengenai kelompok manajemen yang berbeda, memotivasi untuk dilakukannya penelitian lebih lanjut dengan memfokuskan pada apresiasi dan toleransi untuk diversitas yang dapat ditingkatkan dan menyeimbangkan kesempatan yang ada dalam organisasi. Tilikan dari studi feminis tentang gender dan diversitas sebagai highlight memberikan kesempatan untuk dilakukannya studi yang mendalam mengenai hal ini.

Dari penjelasan di atas, penulis mempertimbangkan aspek diversitas sebagai faktor yang dapat memengaruhi pembuatan keputusan dengan proposisi berikut ini.

Proposisi 2a. Diversitas dalam kepemimpinan transformasional berdampak terhadap pembuatan keputusan.

Proposisi 2b. Diversitas dalam kepemimpinan transaksional berdampak terhadap pembuatan keputusan.

\section{METODE PENELITIAN}

Studi ini mengusulkan suatu model konseptual tentang kepemimpinan, gender dan diversitas dalam membuat keputusan organisasi. Studi ini menggunakan pendekatan kuantitatif, eksploratif, dan eksploratori. Pendekatan kuantitatif digunakan untuk menginvestigasi hubungan antar variabel independen dan dependen. Variabel independen penelitian ini adalah gaya kepemimpinan, gender, dan diversitas. Sementara, variabel dependen adalah pembuatan keputusan. Pendekatan eksploratif dilakukan untuk memungkinkan penulis mengembangkan proposisi yang belum diteliti dalam konteks tertentu. 
Penulis menyarankan untuk melakukan pencarian literatur untuk memilih studi yang relevan dengan isu penelitian ini. Awalnya, penulis akan menggunakan kata kunci kepemimpinan dan efektivitas kepemimpinan untuk literatur reviu. Kemudian, studi yang menggunakan kata kunci tersebut dicari secara manual untuk mengetahui perbedaan gender terhadap outcome kepemimpinan. Selain itu, penulis akan mencari kata kunci pemimpin, kepemimpinan, manajer, dan CEO untuk dipasangkan dengan istilah jenis kelamin, perbedaan jenis kelamin, dan perempuan di banyak artikel reviu, buku, prosiding, dan jurnal-jurnal yang relevan dengan isu penelitian ini.

Studi ini mengikuti studi yang dilakukan oleh Eagly et al (1995) dan Underdahl et al (2014) dalam hal metaanalisis untuk konsep gender dan kepemimpinan. Metaanalisis yang dilakukan meliputi: (a) membandingkan pemimpin, eksekutif, manajer, direktur, CEO lakilaki dan perempuan, (b) partisipan berusia minimal 18 tahun, (c) studi ini menilai keefektifan setidaknya lima pemimpin dari setiap jenis kelamin, dan (d) ukuran efektivitas kepemimpinan. Sementara diversitas juga dilakukan metaanalisis dengan merujuk konsep yang dikembangkan oleh Schedlitzki dan Edwards (2014) dan studi terdahulu yang relevan dengan isu diversitas.

\section{DISKUSI DAN PEMBAHASAN}

Secara umum, studi ini mengkonfirmasi dan memperluas pemahaman kita tentang hubungan antara gender, diversitas, dan efektivitas kepemimpinan melalui metaanalisis. Studi ini mengikuti studi Eagly et al (1995) dan Underdahl et al (2014). Studi ini dibangun berdasarkan teori kesesuaian peran dengan membingkainya sedemikian rupa (seperti pada Proposisi 1a, 1b, 2a, dan 2b) yang dikaitkan dengan pembuatan keputusan:

a. Mengidentifikasi konstruk tambahan seperti praktik keseimbangan gender dan kepemimpinan

b. Menawarkan tilikan baru tentang potensi penyelarasan sifat-sifat feminine dan efektivitas kepemimpinan.

Hasil reviu yang kami lakukan menunjukkan bahwa kepemimpinan transaksional dan transformasional berbeda. Seorang pemimpin yang baik seharusnya mengkombinasikan kedua tipe kepemimpinan ini. Di sisi lain, Rawung et al (2015) menyarankan bahwa kepemimpinan transaksional dan transformasional seperti pendulum yang mana reward kontinjen sangat dekat dengan gaya hidup yang diusulkan oleh kepemimpinan 
transformasional. Oleh karena itu, mungkin terdapat korelasi yang tinggi di antara kepemimpinan transformasional dan transaksional.

Ketika organisasi memiliki partisipasi perempuan yang lebih banyak dalam manajemen dan dewan administrasi, penggunaan praktik berorientasi kepemimpinan transformasional cenderung didorong dibandingkan kepemimpinan transaksional. Hasil penelitian $\mathrm{Wu}$ (2010) menemukan bahwa terdapat perbedaan gender dan kesamaan gender pada gaya kepemimpinan yang diharapkan. Namun, perbedaan antara pemimpin laki-laki dan perempuan tidak terlalu kuat. Temuan $\mathrm{Wu}$ (2010) menunjukkan bahwa pemimpin perempuan cenderung memiliki skor yang lebih tinggi pada kepemimpinan transformasional daripada pemimpin laki-laki. Temuan ini memberikan bukti bahwa seorang pemimpin yang berhubungan dengan masyarakat harus memberikan penghargaan psikologis, seperti pujian atas pemenuhan kewajiban yang sudah diberikan.

Studi yang dilakukan oleh Underdahl et al (2014) tentang dampak gender terhadap efektivitas pemimpin memberikan temuan bahwa literatur cenderung terlalu menyederhanakan keunggulan gender dalam kepemimpinan. Konsisten dengan teori kesesuaian peran, sejauhmana organisasi yang diuji didominasi oleh laki-laki atau perempuan secara signifikan memoderasi perbedaan gender dalam efektivitas kepemimpinan. Secara keseluruhan, organisasi yang didominasi oleh laki-laki menunjukkan bahwa kecenderungan laki-laki dianggap lebih efektif untuk memimpin dibandingkan perempuan. Temuan ini konsisten pula dengan metaanalisis yang dilakukan oleh Eagly et al (1995).

Selain itu, sesuai dengan penelitian Eagly dan Karau (2002), perempuan dipandang lebih efektif berada di posisi manajemen menengah dibandingkan laki-laki. Temuan ini konsisten pula dengan temuan metaanalisis Eagly et al (1995) dan Underdahl et al (2014). Secara spesifik Underdahl et al (2014) menemukan bahwa laki-laki cenderung menilai dirinya lebih efektif memimpin dibanding perempuan ketika laki-laki berada pada supervisor level posisi yang lebih rendah dan pemimpin senior. Sementara, utuk penilaian efektivitas kepemimpinan lainnya, perempuan dinilai lebih efektif sebagai manajer menengah dan pemimpin senior. Dari metaanalisis tersebut dapat disimpulkan bahwa terdapat perbedaan gender yang tidak signifikan dalam penilaian efektivitas kepemimpinan lainnya untuk supervisor level bawah.

Lebih lanjut, hasil metaanalisis menunjukkan bahwa laki-laki sebagai pemimpin cenderung kurang efektif dibandingkan perempuan ketika berada pada posisi manajemen 
level menengah. Kemungkinan, posisi manajemen level menengah dianggap feminin. Adanya perbedaan gender pada manajemen level mengisyaratkan bahwa efektivitas kepemimpin untuk level posisi yang lebih rendah karena adanya karakteristik netral gender yang terkait dengan posisi tersebut. Namun, hasil metaanalisis menunjukkan bahwa adanya hipotesis yang bertentangan dengan teori kesesuaian peran. Hasil metaanalisis menemukan bahwa kepemimpinan perempuan dipandang lebih efektif (menurut pandangan orang lain) ketika perempuan memegang posisi manajemen level senior (atas). Ini sejalan dengan model kompetensi standar ganda yang dikembangkan oleh Foschi (2000). Foschi (2000) mengusulkan bahwa perempuan dapat dipandang efektif dibandingkan laki-laki dalam posisi kepemimpinan puncak karena persepsi kompetensi ekstra mereka. Usulan ini juga didukung oleh penelitian Rosette dan Tost (2010). Dari temuan ini dapat dijelaskan bahwa teori kesesuaian peran dapat dilengkapi dengan model kompentensi standar ganda. Artinya model kompetensi standar ganda menjelaskan bahwa persepsi ekstra akan berpotensi mengesampingkan persepsi tentang ketidaksesuaian perempuan dan meningkatkan penilaian efektivitas mereka di level puncak (atas).

Selanjutnya, Underdahl et al (2014) menginvestigasi peran setting studi yang dimoderatori oleh sumber peringkat dalam menjelaskan hubungan gender dan kepemimpinan. Dalam metaanalisis yang dilakukan oleh Underdahl et al (2014) tidak ditemukan dampak signifikan dari peran setting studi secara keseluruhan. Namun, Underdahl et al (2014) melaporkan bahwa terdapat perbedaan yang signifikan ketika menganalisis berdasarkan sumber peringkat. Dalam 64 studi laboratorium yang dilakukan, perempuan dinilai (oleh orang lain) secara signifikan lebih efektif daripada laki-laki dalam organisasi. Lebih lanjut, terdapat perbedaan gender yang tidak berbeda secara signifikan dalam 10 studi laboratorium. Temuan ini mengindikasikan bahwa beban kognitif mengarah pada peningkatan penggunaan stereotip berlaku daripada mengandalkan stereotip tentang efektivitas kepemimpinan laki-laki yang lebih besar. Anggota organisasi mungkin mengandalkan stereotip baru yang berbeda bahwa perempuan adalah pemimpin yang lebih efektif (Underdahl et al 2014).

Metaanalisis yang dilakukan oleh Eagly et al (1995) menemukan adanya efek linier yang signifikan untuk persentase bawahan laki-laki terhadap perbedaan gender yang dilihat dari proporsi jumlah laki-laki yang meningkat. Ini mengindikasikan bahwa kepemimpinan cenderung efektif ketika dipimpin oleh laki-laki. Sementara, Underdahl et al (2014) menemukan hasil yang berlawanan dengan Eagly et al (1995) bahwa perbedaan gender dalam 
efektivitas kepemimpinan cenderung tidak berbeda ketika penilai laki-laki meningkat. Underdahl et al (2014) menemukan bahwa ketika penilai perempuan meningkat, pemimpin perempuan dipandang sebagai pemimpin yang lebih efektif dibandingkan laki-laki. Perbedaan ini menjadi rendah ketika diuji pada kelompok yang jumlah gendernya seimbang. Lebih lanjut, Underdahl et al (2014) menyarankan bahwa ketika persentase penilai perempuan meningkat (seorang pemimpin laki-laki akan menjadi tanda status tinggi), laki-laki harus dilihat lebih kongruen. Dengan demikian, laki-laki sebagai pemimpin akan lebih efektif daripada perempuan (Eagly dan Karau 2002). Sebaliknya, Underdahl et al (2014) menemukan bahwa persentase penilai perempuan secara positif memengaruhi penilaian efektivitas perempuan. Ini menunjukkan bahwa penerapan teori kesesuaian peran untuk peran pemimpin laki-laki dan perempuan sangat tergantung pada konteks atau situasi. Jika stereotip telah bergeser sedemikian rupa, perempuan dapat dianggap sebagai pemimpin yang lebih baik daripada laki-laki.

Metaanalisis ini berkontribusi pada perdebatan dalam literatur tentang keunggulan gender (laki-laki versus perempuan) terhadap efektivitas kepemimpinan. Secara umum ditemukan bahwa ketika semua konteks kepemimpinan dipertimbangkan bersama, maka perbedaan gender menjadi tidak signifikan dalam efektivitas kepemimpinan. Lebih penting lagi, studi ini mengeksplorasi dalam literatur hubungan gender dan efektivitas kepemimpinan dalam pembuatan keputusan dengan menambahkan diversitas berdasarkan teori kesesuaian peran dan beberapa kerangka konsep tambahan.

\section{SIMPULAN}

Dalam tulisan ini, penulis menyarankan sebuah model konseptual untuk kepemimpinan, gender, dan diversitas. Gaya kepemimpinan telah mengalami pergeseran paradigma, dari kepemimpinan stereotype maskulin (yang melekat pada pemimpin laki-laki) ke kepemimpinan perempuan. Penulis juga menawarkan faktor diversitas seperti gender, kepemimpinan ekspatriat, dan manajemen yang berkaitan dengan gaya kepemimpinan dalam membuat keputusan organisasi dengan memperhatikan faktor lintas kultur dan lintas organisasi. Keefektifan kepemimpinan memiliki pengukuran yang beragam antar masingmasing peneliti.

Studi ini dibangun berdasarkan teori kesesuaian peran yang mengemukakan bahwa pemimpin perempuan dapat memimpin sama efektifnya dengan pemimpin laki-laki, bahkan tak jarang pemimpin perempuan lebih efektif memimpin daripada pemimpin laki-laki. 
Pemimpin perempuan bercirikan lebih mengutamakan keharmonisan lingkungan kerja, meminimalisir konflik, dan membangun komunikasi atau hubungan yang intens dengan berbagai pihak, dan tidak segan untuk membagi informasi atau mendengarkan komplain dari bawahannya. Gambaran ini dikenal dengan gaya kepemimpinan demokratis, transformasional, dan consideration oriented. Sebaliknya dengan kepemimpinan laki-laki yang lebih mengutamakan kontrol, perintah, mengembangkan kompetisi, dan initiating structure, serta berorientasi pada tugas.

Adanya diversitas juga mempengaruhi keefektifan kepemimpinan. Diversitas tak hanya dilihat dari gender, etnis, umur, gender, pendidikan, kelas, dan orientasi seksual. Tetapi diversitas yang menjadi perhatian dalam literatur organisasional dan kepemimpinan saat ini dilihat dari pemimpin ekspatriat dan kultur lokal di tempat kerja, diversitas manajemen dalam hal memanfaatkan potensi yang beragam dari masing-masing tenaga kerja.

Studi di area gender dan kepemimpinan telah banyak menjadi objek kajian, namun studi di area kepemimpinan dan diversitas masih terbatas dilakukan. Isu kepemimpinan dan diversitas menjadi hal yang perlu dipertimbangkan untuk studi mendatang. Hal krusial dalam kepemimpinan adalah bagaimana pemimpin mampu menjalankan kepemimpinannya dengan efektif dengan menyesuaikan pada gaya kepemimpinan yang tepat, sesuai dengan kebutuhan dan karakteristik situasi tertentu, dengan mempertimbangkan berbagai diversitas yang ada dalam organisasi.

\section{DAFTAR PUSTAKA}

Astin, A. W., Parrott, S. A., Korn, W. S., \& Sax, L. J. (1997). The American freshman: Thirty year trends. Los Angeles: Higher Education Research Institute, University of California.

Avolio, B. J. and Howell, J. M. 1992. The impact of leader behaviour and leader-follower personality match on satisfaction and unit performance, in Clarke, K. E. Clarke, M. B., and CampbellD. R. (Eds.). Impact of Leadership, Greensboro, NC, The Center for Creative Leadership.

Bass, B.M. 1990. From Transactional to Transformational Leaders: Learning to Share the Vision. Organizational Dynamics, 18(3), 19-31.

Bass, B. M. 1997. Does the transactional- transformational leadership paradigm transcend organizational and national boundaries? American Psychologist, 52, 130-139.

Bass, B.M. and Avolio, B.J. 1994. Improving Organizational Effectiveness Through Transformational Leadership, Sage, Thousand Oaks, CA.

Berger, J., Fisek, M. H., Norman, R. Z., \& Zelditch, M. (1977). Status characteristics and social interaction. New York, NY: Elsevier Scientific. 
Diekman, A. B., \& Eagly, A. H. (2000). Stereotypes as dynamic constructs: Women and men of the past, present, and future. Personality and Social Psychology Bulletin, 26, p. 1171 $-1188$

Dobbins, G. H., \& Platz, S. J. (1986). Sex differences in leadership: How real are they? Academy of Management Review, 11, p. $118-127$.

Dwiri, B., dan Okatan, K. 2021. The impact of gender on leadership styles and leadership effectiveness. International Journal of Science and Research. DOI: 10.21275/SR21126183926.

Eagly, A. H., dan Johnson, B. T. 1990. Gender and leadership style: a meta-analysis. Psychological Bulletin, 108 (2), p. 233 - 256.

Eagly, A. H., dan Johannesen Schmidet, M. C. 2001. The leadership styles of women and men. Journal of Social Issues. 57(4), p. $781-797$.

Eagly, A. H., Johannesen Schmidt, M. C., dan Van Engen, M. L. 2003. Transformational, transactional, and laissez faire leadership styles: A meta analysis comparing women and men. Psychological Bulletin, 129 (4), p. 569-591

Eagly, A. H. 2007. Female leadership advantage and disadvantage: Resolving the contradictions. Psychology of Women Quarterly, 31 (1), 12.

Eagly, A. H., \& Karau, S. J. (2002). Role congruity theory of prejudice toward female leaders. Psychological Review, 109, 573-598. doi: 10.1037/0033-295X.109.3.573.

Elliot, C., dan Stead, V. 2008. Learning from leading women's experience: Towards a sociological understanding.

http://www.uk.sagepub.com/northouse5e/study/articles/pdfs/13-Elliot.pdf

Fagenson, E. A. 1990. At the heart of women in management research: Theoretical and methodological approaches and their biases. Journal of Business Ethics, 9, p. 267-274.

Foschi, M. 2000. Double standards for competence: Theory and research. Annual Review of Sociology, 26, p. 21-42. doi:10.1146/annurev.soc.26 .1.21.

Gardiner, M., dan Tiggermann, M. 1999. Gender differences ini leadership style, job stress, and mental health in male and female dominated industries. Journal of Occupational and Organizational Psychology, 72(3), p. 121-134.

Glick, P., Lameiras, M., Fiske, S. T., Eckes, T., Masser, B., Volpato, C. 2004. Bad but bold: Ambivalent attituedes toward men predict gender inequality in 16 nations. Journal of Personality and Social Psychology, 86 (5), p. 713 - 728.

Handayani, C. S., dan Novianto, A. 2004. Kuasa Wanita Jawa. Yogyakarta: Lukis Pelangi Aksara.

Handriana, Tanti. 2011. Gender dalam keefektifan kepemimpinan transformational. Majalah Ekonomi, Tahun XXI, No. 1.

Hater, J. J. and Bass, B. M. 1988. "Supervisors evaluations and subordinatese perceptions of transformational leadership". Journal of Applied Psychology,73, p. 695-702.

Heilman, M. E. (2001). Description and prescription: How gender stereotypes prevent women's ascent up the organizational ladder. Journal of Social Issues, 57, 657-674. doi:10.1111/0022-4537.00234.

House, R. J. 1971. A path goal theory of leader effectiveness. Administrative Science Quarterly, 16 (3), p. 321-339.

Jackson dan Parry. 2011. Follower-centred Perspectives on Leadership. http://www.sagepub.com/upm-data/40601_9781849207393.pdf 
Konrad, A. M., Corrigall, E., Lieb, P., \& Ritchie, J. E. (2000). Sex differences in job attribute preferences among managers and business students. Group and Organization Management, 25 (2), p. 108 - 131.

Kusumawati, Andriani. 2007. Kepimpinan Dalam Perspektif Gender: Adakah Perbedaan? Jurnal Administrasi Bisnis, 1 (1)

Lewis, A. E., dan Fagenson-Eland, E. A. 1998. The influence of gender and organization level on perceptions of leadership behaviors: A self and supervisor comparison. Sex Role, 39 $(5 / 6), 479-502$.

Lowe, K.B., Kroeck, K.G., \& Sivasubramaniam, N. (1996). Effectiveness Correlates of Transformational and Transactional Leadership: A Meta-Analytic Review of The MLQ Literature. Leadership Quarterly, 7(3), 385-425.

Miner, J.B. 1980. Theories of Organizational Behavior. Hinsdale, III: The Dryden Press.

Nayab, N. (2010). Characteristics of Transformational Leadership. http://www.brighthubinc./March 23, 2011.

Nurmayanti M, Poppy. 2019. Karakteristik direktur utama dan kualitas laba dalam perspektif variasi pola-pola aliran kas. Disertasi Program Studi Doktor Ilmu Akuntansi Fakultas Ekonomika dan Bisnis Universitas Gadjah Mada. Yogyakarta.

Powell, G. N. 1990. One more time: Do male and female managers differs? Academy of Management Executive, 12, p. 731 - 743.

Powell, G. N. 2012. Six ways of seeing the elephant: the intersection of sex, gender, and leadership. Gender in Management: An International Journal, Vol. 27 No. 2, pp. 119141.

Rawung, F., Wuryaningrat, N. and Elvinita, L. 2015, The influence of transformational and transactional leadership on knowledge sharing: an empirical study on small and medium businesses in Indonesia. Asian Academy of Management Journal 20 ( 1), p. 123-145

Ridgeway, C. L. 1997. Interaction and the conservation of gender inequality: Considering employment. American Sociological Review, 62, 218 -235. doi:10.2307/2657301.

Ridgeway, C. L. 2001. Gender, status, and leadership. Journal of Social Issues, 57, 637- 655. doi:10.1111/0022-4537.00233.

Rosette, A. S., dan Tost, L. P. 2010. Agentic women and communal leadership: How role prescriptions confer advantage to top women leaders. Journal of Applied Psychology, 95, 221-235. doi:10.1037/a0018204

Saeed, T., Almas, S., Anis-ul-Haq, M., Niazi, G.S.K. 2014, Leadership styles: Relationship with conflict management styles. International Journal of Conflict Management, 25(3), 214-225.

Schedlitzki, D., dan Edwards, G. 2014. Chapter 12: Leadership, Gender, and Diversity. http://www.sagepub.com/upm data/61014_Schedlitzki_and_Edwards_Final_Proof_ch12.pdf.

Schein, V. E. (1973). The relationship between sex role stereotypes and requisite management characteristics. Journal of Applied Psychology, 57, 95-100. doi:10.1037/h0037128.

Schein, V. E. 2007. Women in management: Reflections and projections. Women in Management Review, 22, p. 6 - 18. doi: 10.1108/09649420710726193

Seltzer, J and Bass, B. M. 1990. "Transformational leadership: beyond initiation and consideration". Journal of Management, Vol. 16: 693-703

Smith PB, Wang ZM. 1996. Chinese leadership and organizational structure. In MH, Bond. eds. The handbook of Chinese psychology. Hong Kong: Oxford University Press.

Smith PB, Bond MH. 1993. Social psychology across cultures: Analysis and perspectives. Needham, MA: Allyn and Bacon. 
Underdahl, S. C. P., Walker, L. S., dan Woehr, D. J. 2014. Gender and perceptions of leadership effectiveness: A meta-analysis of contextual moderators. Journal of Applied Psychology, 99 (6), p. 1129 - 1145.

Van Emmerik, Hetty., Wendt, Hein., dan Euwerna, C.M. 2009. Gender ration, societal culture, and male and female leadership. Journal of Occupational and Organizational Psychology, p. 1-21.

Vanconcelos, A. F. 2018. Gender and leadership stereotypes theory: is it reaching the boundaries?. Management Research Review, https://doi.org/10.1108/MRR-04-20170131.

Vecchio RP, Bullis RC. 2001. Moderators of the influence of supervisor-subordinate similarity on subordinate outcomes. Journal of Applied Psychology, 86(5): 884- 896.

Wu, Ming-Yu. 2010. Gender and cultural influences on expected leadership styles. China Media Research 6 (1), p. 37-46.

Yammarino, F. J., Dionne, S. D., Uk Chun, J., dan Dansereau, F. 2005. Leadership and levels of analysis: A state-of-the-science review. Leadership Quarterly, 16 (6), p. 879 - 919.

Yukl, G. A. 1989. Leadership in organizations. 2nd ed. Prentice-Hall, Inc. 